УДК 638.145 .3

(C)2012

Субота Ю. В., завідувач відділу,

Григорків Л. М., науковий співробітник

Національний науковий центр «Інститут бджільництва ім. П. І. Прокоповича»

\title{
ВПЛИВ НАЯВНОСТІ ТРУТНІВ У СІМ'Ї НА ВИРОЩУВАННЯ ТРУТНЕВОГО РОЗПЛОДУ
}

Рецензент - кандидат сільськогосподарських наук Г. М. Гречка

Досліджено вирощування бджолами трутневого розплоду. Встановлено, щзо видалення трутнів із сім'ї під час інтенсивного розвитку в червні й липні призводить до збільшення кількості трутневого розплоду. Відносно бджолиного, його зростання становить від 4,0\% до 7,6-11,7\%, і процес вирощування трутнів триває довше на 30 днів. Бджолині сім'ї украӥнської степової породи активно коригують чисельність трутнів у родинах. До того ж після повного їх видалення із сімей, через тричотири дні в них знову знаходили самиів, при чому значно більше, ніж було виявлено розплоду. Можливо, відбір трутнів із сімей сприяв зальоту в них чужих.

Ключові слова: трутні, трутневий розплід, бітьківські сім '̈̈, бджолиний розплід.

Постановка проблеми. Бджільництво досягло значних успіхів у розведенні та утриманні бджіл. Розроблено методи, що дають змогу отримати від бджолиних сімей більшу кількість продукції та використовувати їх на запиленні ентомофільних культур. Однак, подальше збільшення продуктивності пасік проходитиме значно ефективніше за покращання якості бджіл. Трутні, як і бджолині матки, є носіями спадкової інформації. Щоб не погіршувалися спадкові властивості, що передаються ними при заплідненні маток, трутнів необхідно вирощувати в кращих батьківських сім'ях. Для успішного отримання значної кількості трутнів бажаного походження необхідно вивчити біологічні особливості їх вирощування та утримання.

Аналіз основних досліджень і публікацій, у яких започатковано розв'язання проблеми. Вирощування бджолосім'ями трутнів залежить від їх сили, надходження кормів, пори року, віку матки, генетичних особливостей, кількості наявних трутнів і трутневого розплоду в них.

Обмеження вирощування бджолами трутневого розплоду пов'язано передусім із тим, що личинки й дорослі трутні з'їдають багато корму [2].

Кількість трутневого розплоду, вирощеного сім'ями протягом активного сезону, в різних дослідників визначена неоднаково. Так, К. Вайс (1962) вважає, що вона становить 4,6\%, а Дж. Фрі (1975) - 15-16\% від кількості всього розплоду [4, 3]. Російські вчені, досліджуючи бджолосім'ї центральної частини Росії, встановили, що кількість трутневого розплоду в них коливалася від 1 до $15 \%$, змінюючись залежно від наявності бджолиного розплоду [1].

$€$ багато чинників, які можуть коригувати вирощування трутнів, але з практики відомо, що основну роль відіграє присутність у сім'ї трутнів і трутневого розплоду. Тому важливо встановити ступінь впливу цього фактора на процес вирощування самців української степової породи.

Мета досліджень. Метою досліджень $\epsilon$ визначення впливу наявності трутнів у сім'ї на вирощування трутневого розплоду та на появу в ній нових трутнів.

Матеріали і методи досліджень. Дослідження проводили на пасіці ННЦ «Інститут бджільництва ім. П. І. Прокоповича», де утримуються бджоли української степової породи, використовуючи при цьому зоотехнічний, обліковий і статистичний методи.

У червні було сформовано дві групи бджолиних сімей-аналогів, по три в кожній групі. В досліджуваних сім'ях протягом сезону видаляли через кожні три-шість днів усіх трутнів. Контрольні сім'ї - звичайні, із природним розвитком трутнів і трутневого розплоду в них трутнів не видаляли. В ці ж дні проводили обліки кількості трутневого розплоду та трутнів.

Результати досліджень. Вплив регулярного видалення трутнів із сім'ї на вирощування трутневого розплоду показано на рисунку, а зміни співвідношення трутневого та бджолиного розплоду подано в таблиці.

Як бачимо, штучне видалення із гнізда майже всіх живих трутнів призводить до різкого збільшення (в десятки разів) вирощування трутневого розплоду до кінця червня. 


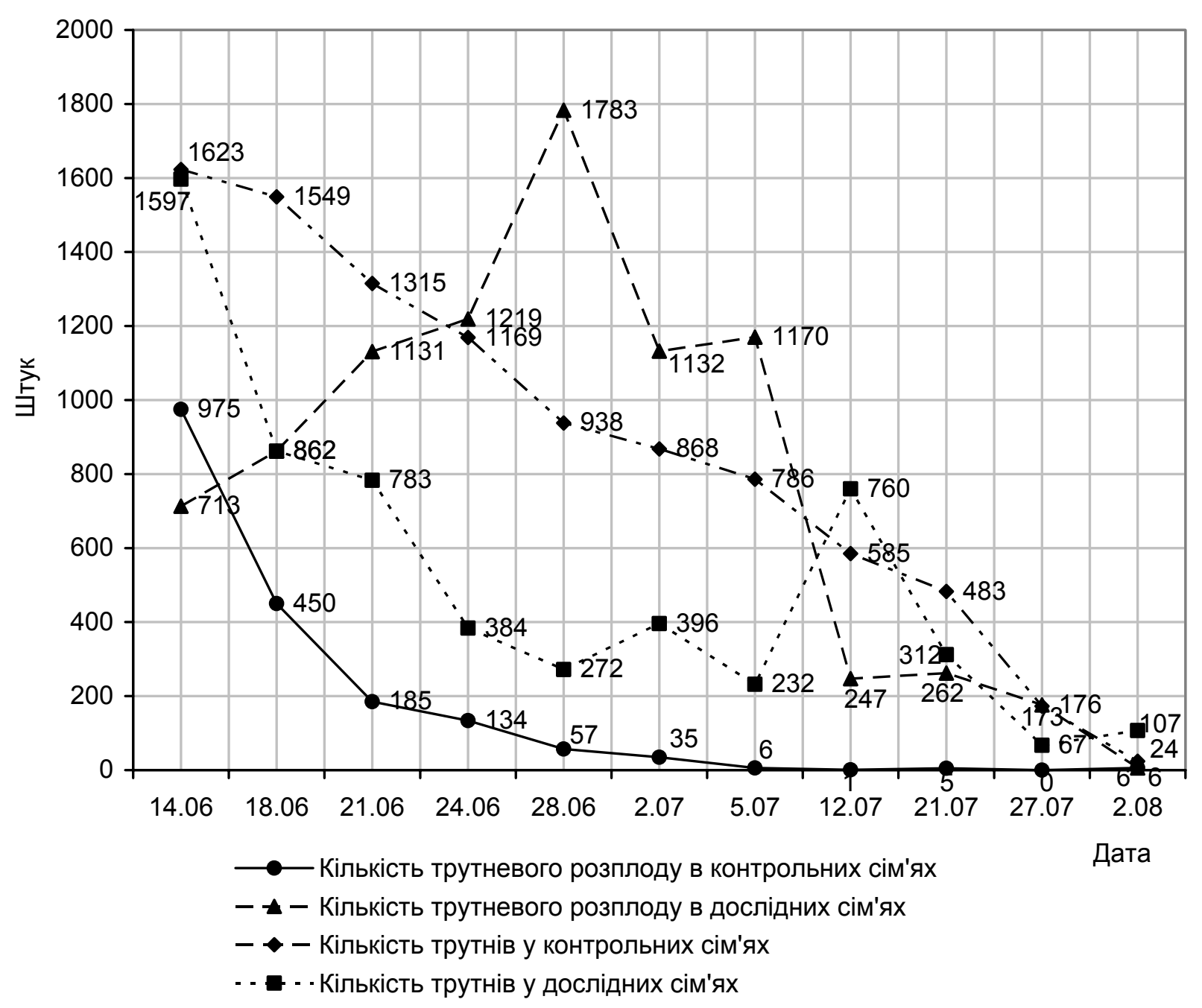

Рис. Кількість трутневого розплоду і трутнів у дослідних і контрольних сім'ях (ит. комірок)

Кількість та співвідночення трутневого та бджолиного розплоду, 2010 р., $n=3$

\begin{tabular}{|c|c|c|c|c|c|c|}
\hline \multirow[b]{2}{*}{ Дата } & \multicolumn{3}{|c|}{ Контроль } & \multicolumn{3}{|c|}{ Дослід } \\
\hline & $\begin{array}{c}\text { трутневий } \\
\text { розплід, } \\
\text { шт. ком., } \\
\mathrm{M} \pm \mathrm{m}\end{array}$ & $\begin{array}{c}\text { бджолиний } \\
\text { розплід, } \\
\text { шт. ком., } \\
\mathrm{M} \pm \mathrm{m}\end{array}$ & $\begin{array}{c}\text { трутневого } \\
\text { розплоду } \\
\%\end{array}$ & $\begin{array}{c}\text { трутневий } \\
\text { розплід, } \\
\text { шт. ком., } \\
\text { М } \pm \mathrm{m}\end{array}$ & $\begin{array}{c}\text { бджолиний } \\
\text { розплід, } \\
\text { шт. ком., } \\
\mathrm{M} \pm \mathrm{m}\end{array}$ & $\begin{array}{c}\text { трутневого } \\
\text { розплоду, } \\
\%\end{array}$ \\
\hline 14.06 & $975 \pm 121$ & $21500 \pm 305$ & 4,50 & $723 \pm 108$ & $20700 \pm 2640$ & 3,4 \\
\hline 28.06 & $57 \pm 9$ & $17300 \pm 1169$ & 0,30 & $1783 \pm 217$ & $15200 \pm 840$ & 11,7 \\
\hline 5.07 & $6 \pm 2,5$ & $16900 \pm 37$ & 0,04 & $1170 \pm 209$ & $15300 \pm 3577$ & 7,6 \\
\hline 21.07 & $5 \pm 1,5$ & $11200 \pm 2919$ & 0,04 & $262 \pm 25,5$ & $7900 \pm 289$ & 3,3 \\
\hline 2.08 & $6 \pm 3,2$ & $8330 \pm 1590$ & 0,07 & $0 \pm 0$ & $4600 \pm 2320$ & 0 \\
\hline
\end{tabular}

Далі кількість трутневого розплоду зменшується, але підтримується на досить високому рівні ще ввесь липень, в той час як у контрольних, звичайних сім'ях, цей показник сходить майже до нуля. Тобто, інтенсивне вирощування трутнів подовжується майже на місяць. Різниця в кількості трутневого розплоду в сім'ях достовірна (td 3,5-10,1). Міняється і співвідношення кількості бджолиного та трутневого розплоду. Якщо в контрольних сім'ях у червні під час інтенсивного розвитку (згідно з даними попередніх років і літературних даних), загальна кількість трутневого розплоду, відносно бджолиного, становить близько $4 \%$, то при видаленні самців із сімей 
цей показник збільшується до 7,6-11,7 \% і зберігається довше на місяць. Аналогічне співвідношення спостерігається при підстановці у сім’і одного-двох трутневих стільників. Бджолина сім'я, як біологічний організм, має потреби в певній кількості самців. Так, у перші 14 днів досліджень ми помітили в гніздах значну кількість трутнів, хоча їх повністю видаляли 3 сімей кожні три-чотири дні. Можливо, відбір чоловічих особин із сімей сприяв зальоту в них чужих. Але як вони відчували відсутність самців у цих роди-

\section{БІБЛІОГРАФІЯ}

1. Лебедев В. И. Заготовка личинок трутней это выгодно / В. И. Лебедев, Н. А. Легович // Пчеловодство, 2003. - № 3. - С. 52-54.

2. Руттнер Р. Матководство / Р. Руттнер. - Бухарест, 1981. $-293 \mathrm{c}$. нах, адже ці сім'ї нормально функціонували? Єдине виключення - це збільшення кількості трутневого розплоду, що невластиво для певного періоду. Та чи могло бути це причиною такої поведінки? Факт потребує перевірки.

Висновки. Видалення трутнів із сімей у червні й липні призводить до збільшення кількості трутневого розплоду. Відносно бджолиного його кількість зростає 3 4,0\% до 7,6-11,7\% і зберігається в сім'ях він довше на 30 днів.

3. Free I. B. Faactors determining the rearing and rejection Behov. - 1975. - №23. - P. 650-675.

4. Weiss Karl. Vntersaehungen vber die Drohnenerreugung im Bienenvolk / Karl Weiss // Arch. Bienenkuhde. - 1962. - 39. - №1. - P. 1-7. 